FALL/AUTOMNE 2010, ISSUE / N²
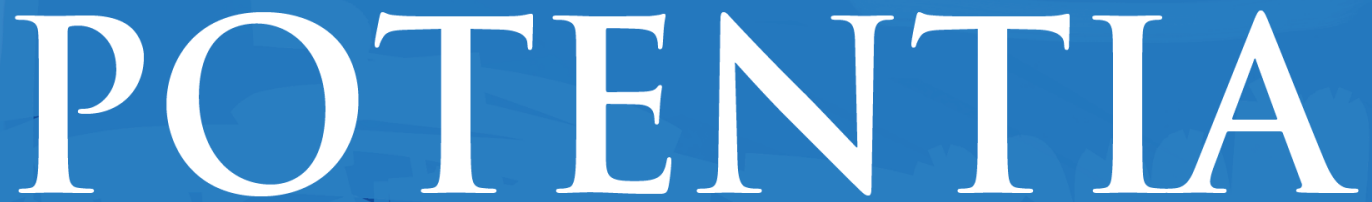

THE CENTRE FOR INTERNATIONAL POLICY STUDIES (CIPS) GRADUATE STUDENT JOURNAL REVUE DES ÉTUDIANT(E)S DIPLÔMÉ(E)S DU CENTRE D'ÉTUDES EN POLITIQUES INTERNATIONALES (CÉPI)
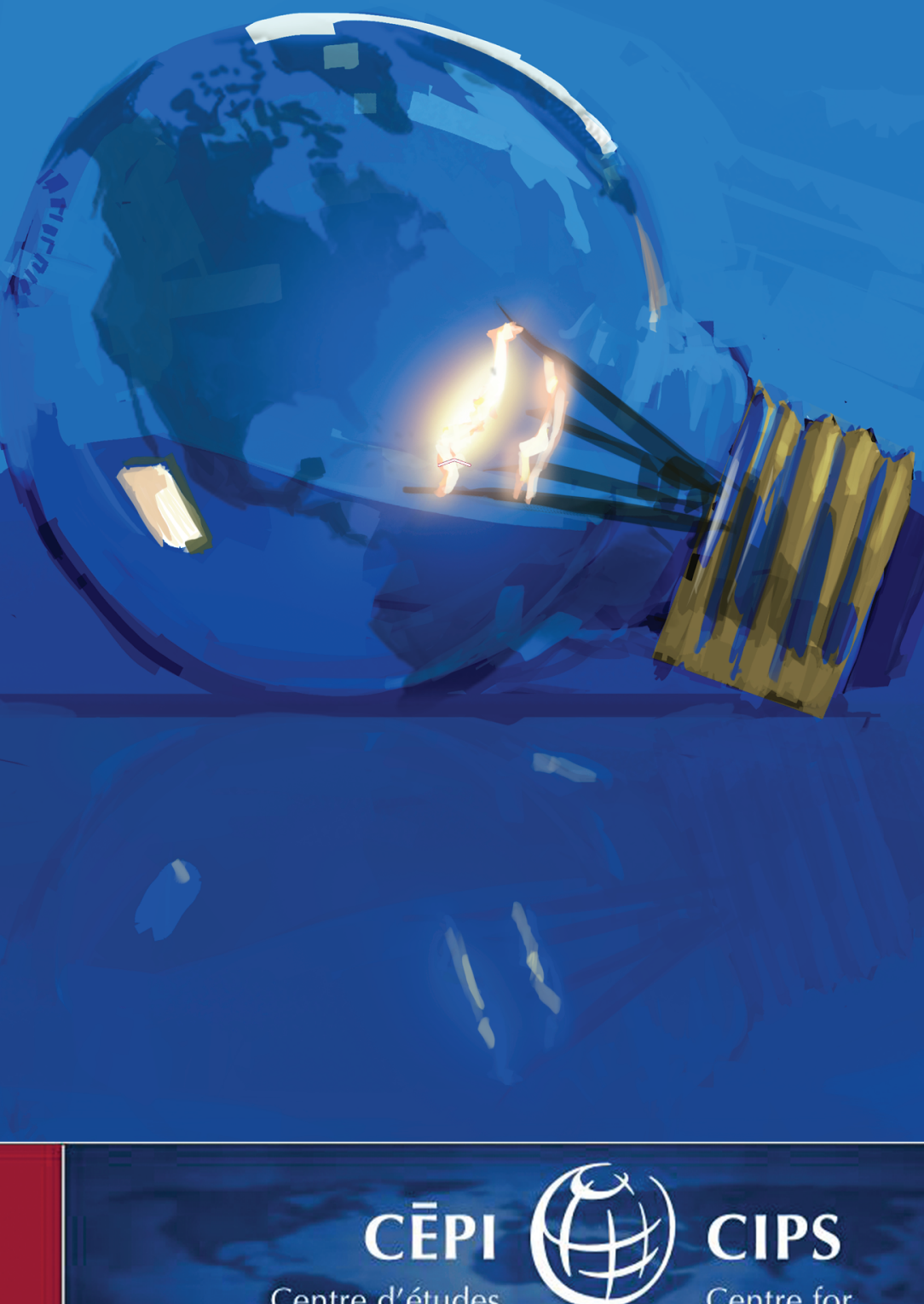

Centre d'études

Centre for

uOttawa

EN POLITIQUES INTERNATIONALES

INTERNATIONAL POLICY STUDIES 


\section{Avant-propos | Foreword}

Cette édition constitue le deuxième numéro de la Revue des étudiants aux cycles supérieurs du Centre d'études en politiques internationales, Potentia. While the journal is still in its infancy, this has been a monumental year for Potentia.

Last year's inaugural edition included seven articles written by graduate students from the University of Ottawa. This year, we expanded our borders by opening our call for papers to students of all Canadian universities. Nous avons ainsi reçu un nombre d'articles excellents provenant d'un éventail de programmes, de diverses universités francophones et anglophones, et de cinq provinces différentes.

The six papers in this edition were selected through an objective review by a committed team of editors. Successful papers were then individually revised by senior editors. All of the papers were selected based on rigorous standards of policy relevance and compelling academic analysis. The selections before you in this edition are significant because they provide insight into challenges Canada and the international system are forecasted to encounter in the near-term.

Le monde est dans un état de crise, et l'effondrement de l'économie globale a laissé de nombreux pays dans des situations financières alarmantes. Les douze derniers mois au cours desquels cette édition a été réalisée ont transformé la façon dont plusieurs voient notre monde; toutefois, nombreux sont les enjeux qui ne changeront pas. Cette édition met en valeur non seulement l'évolution constante de tout ce qui nous entoure, mais également I'assiduité avec laquelle certains problèmes persistent.

Through the collection of critical papers brought together in this journal, a variety of themes and perspectives are explored. New and emerging analytical conceptualisations, such as the notions of human rights and human security, shed light unto our understanding of conflict. No matter how well conflict is understood, however, human suffering sadly remains the norm in the Democratic Republic of the Congo (DRC). As the two papers in this volume that deal with the Congo demonstrate, the DRC cannot be allowed to go unnoticed by Canada or the world. 
Un autre thème traité dans cette revue concerne le terme mondialisation. II était une fois que ce terme ne possédait que de bonnes connotations. Aujourd'hui, on commence de plus en plus à reconsidérer ce phénomène et à se rendre compte des conséquences d'un monde dans lequel les frontières disparaissent tandis que les inégalités demeurent. Other issues also continue to be constant in Canada and around the world. Many students of International Relations will be excited that traditional geopolitical posturing, such as that of the United States and China, and the strategic posturing in Canada's Arctic receive academic analysis in this edition.

Nous espérons sincèrement que vous aimerez cette deuxième édition de la Revue des étudiants aux cycles supérieurs du Centre d'études en politiques internationales, et que les articles que vous trouverez ci dedans inciteront des débats stimulants sur les défis auxquels le Canada ainsi que la communauté internationale font face aujourd'hui et dans les années à venir.

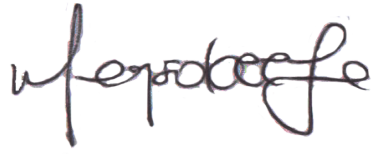

Meghan Spilka O'Keefe

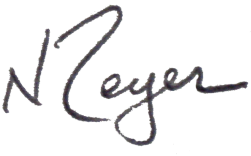

Nathan Reyes

Rédacteurs en chef | Editors-in-Chief

Potentia, 2010 


\section{Remerciements | Acknowledgements}

Nous avons fait face à une multitude de défis au cours de l'année. Sans l'aide de certains individus ainsi que des comités d'étudiants et étudiantes dévoués qui ont travaillé pour rendre cette édition une réussite, nous n'aurions jamais pu apprendre, évoluer et finalement produire la revue que vous lisez en ce moment. Les Rédacteurs en chef de I'année passée, Ian B. Anderson et Kady Seguin, nous ont rendu un service inestimable en nous donnant leur appui et des conseils pendant tout le processus. Judy Meyer et Roland Paris nous ont aussi guidés et conseillés Iorsque nous avions des questions ou des doutes, contribuant ainsi au succès de cette édition.

Marie Spilka O'Keefe, our phenomenal, talented, and dedicated layout designer was indispensable in the last leg of production. The production of this year's edition was made entirely possible by Marie, as she worked Iong hours to ensure that the print deadline was met.

Most importantly, however, are the students who volunteered on the executive or editorial board members. These individuals have been the backbone of this publication. They diligently attended all meetings regardless of their other academic, employment, or extra-curricular commitments. They worked tirelessly to ensure the quality of this year's edition. As well, our highly gifted senior editors that worked individually with the authors proved to be an exceptional resource throughout this process. The dedication of these individuals is unparalleled.

Pour en conclure, nous voudrions surligner l'importance de la qualité exceptionnelle des articles qui ont été soumis à notre revue et qui ont ainsi rendu sa réalisation possible. L'aptitude des auteurs à pousser leur réflexion sur des sujets extrêmement complexes a mis au défi notre capacité et celle de nos rédacteurs d'analyser et de critiquer, et a souvent provoqué des débats académiques enrichissants au sein de nos comités. 
AUTHORS | AUTEURS

Jeffery M. Bernstein

Marie-Hélène L'Heureux

David Moffette

Graham Richardson

Adam Tereszowski

Caroline Trottier

SENIOR EDITORS | RÉDACTEURS SÉNIORS

Laura Biehn

Katie Boon

Irakli A. Gelukashvili

Sahar Ghadhban

Antoine Hamel

Ryan Lebans

Bronwyn Russle

EXECUTIVE BOARD | COMITÉ EXÉCUTIF

Derek Asoh

Katie Boone

Brad Cartier

Viva Dadwal

Catherine Dos Santos

Irakli A. Gelukashvili

Sahar Ghadhban

Susan Hough

Samara Hutton

Valerie Klassen

Dylan Powers

Bronwyn Russel

Dan Warelis
EDITORIAL BOARD | COMITÉ ÉDITORIAL

Derek Asoh

Katie Boone

Anna Borotko

Carolyn Cornford

Viva Dadwal

Catherine Dos Santos

Irakli A. Gelukashvili

Sahar Ghadhban

Antoine Hamel

Susan Hough

Samara Hutton

Mohammad Karimi

Valerie Klassen

Ryan Lebans

Kim McPhail

Dylan Powers

Bronwyn Russel

Laura Shantz

Anastasia Tataryn

Marla Williams

LAYOUT | MISE EN PAGE

Marie Spilka O'Keefe

COVER DESIGN | COUVERTURE

Patrick O'Keefe

EDITORS-IN-CHIEF | RÉDACTEURS EN CHEF

Meghan Spilka O'Keefe

Nathan Reyes 


\section{Tables des matières | Table of Contents}

VERS UNE CULTURE DE PRÉVENTION?

UNE ANALYSE DU CONCEPT DE « SENSIBILITÉ AUX CONFLITS »

Marie-Hélène L'Heureux

Between a Rock and a Hard Place:

Unauthorised Humanitarian Intervention and the Preservation of International Law

Jeffrey M. Bernstein

PrIORISER LA LIBERTÉ DE PRESSE LORS DU PROCESSUS DE DÉMOCRATISATION : DÉSILLUSION

Situation en République démocratique du Congo

Caroline Trottier

The China Threat:

Myths, Realities, and Implications for U.S. Foreign Policy

Graham Richardson

Mondialisation et VIOLENCE SEXISTE :

LE CAS DES tRavailleuses dOMEstiques migrantes au CANAdA

David Moffette

Securing Canada's Sovereignty In The Arctic

Adam Tereszowski 
